\title{
RAD18 Gene
}

National Cancer Institute

\section{Source}

National Cancer Institute. RAD18 Gene. NCI Thesaurus. Code C106244.

This gene plays a role in both protein ubiquitination and DNA repair. 